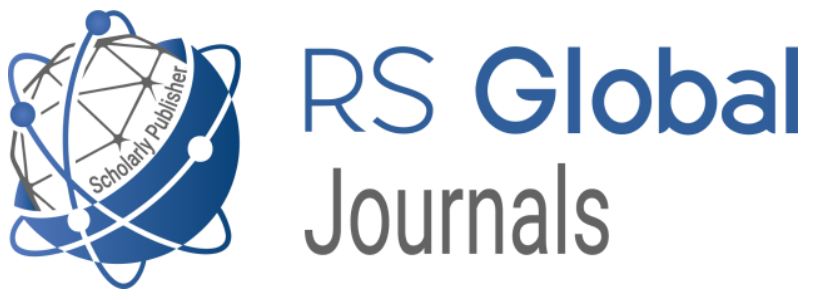

Scholarly Publisher

RS Global Sp. z O.O.

ISNI: 0000000484952390

Dolna 17, Warsaw, Poland 00-773

Tel: +48226022703

Email: editorial_office@rsglobal.pl

JOURNAL International Journal of Innovative Technologies in Social Science

p-ISSN $2544-9338$

e-ISSN

2544-9435

PUBLISHER

RS Global Sp. z O.O., Poland

ARTICLE TITLE

Psychological Peculiarities of Professional Responsibility of Future Specialists of the Civil Defence Service

$\operatorname{AUTHOR}(\mathbf{S})$

Mokhnar L. I., Fomych M. V., Diachkova O. M., Kryshtal M. A.

Mokhnar L. I., Fomych M. V., Diachkova O. M., Kryshtal M. A. (2020) Psychological Peculiarities of Professional Responsibility

ARTICLE INFO of Future Specialists of the Civil Defence Service. International Journal of Innovative Technologies in Social Science. 6(27). doi: 10.31435/rsglobal_ijitss/30092020/7152

DOI https://doi.org/10.31435/rsglobal_ijitss/30092020/7152

RECEIVED

16 July 2020

ACCEPTED

05 September 2020

PUBLISHED

08 September 2020

LICENSE

This work is licensed under a Creative Commons Attribution

4.0 International License.

(C) The author(s) 2020. This publication is an open access article. 


\title{
PSYCHOLOGICAL PECULIARITIES OF PROFESSIONAL RESPONSIBILITY OF FUTURE SPECIALISTS OF THE CIVIL DEFENCE SERVICE
}

\author{
Mokhnar L. I., \\ PhD in Pedagogy, Cherkasy Institute of Fire Safety named after Chornobyl Heroes of the National \\ University of Civil Defence of Ukraine, ORCID ID: https://orcid.org/0000-0001-7753-2345 \\ Fomych M. $V$., \\ PhD in Psychology, Associate Professor, Cherkasy Institute of Fire Safety named after Chornobyl \\ Heroes of the National University of Civil Defence of Ukraine, \\ ORCID ID: https://orcid.org/0000-0003-1253-2656 \\ Diachkova O. M., \\ PhD in Pedagogy, Cherkasy Institute of Fire Safety named after Chornobyl Heroes of the National \\ University of Civil Defence of Ukraine, ORCID ID: https://orcid.org/0000-0001-5164-3522 \\ Kryshtal M. A., \\ Ph.D. in Psychology, Professor, Cherkasy Institute of Fire Safety named after Chornobyl Heroes of \\ the National University of Civil Defence of Ukraine, \\ ORCID ID: https://orcid.org/0000-0003-0701-4731
}

DOI: https://doi.org/10.31435/rsglobal_ijitss/30092020/7152

\section{ARTICLE INFO}

Received 16 July 2020

Accepted 05 September 2020

Published 08 September 2020

\section{KEYWORDS}

responsibility, responsible behaviour, professional responsibility.

\begin{abstract}
The essence of the concept of "responsibility" and "professional responsibility of a rescuer" is revealed in the article; the psychological foundations of the development of responsible behavior are analyzed; the main ways and means that ensure the success of the process of the responsibility formation, the main pedagogical conditions for improving educational activities and the formation of responsibility among the cadets are presented.
\end{abstract}

Citation: Mokhnar L. I., Fomych M. V., Diachkova O. M., Kryshtal M. A. (2020) Psychological Peculiarities of Professional Responsibility of Future Specialists of the Civil Defence Service. International Journal of Innovative Technologies in Social Science. 6(27). doi: 10.31435/rsglobal_ijitss/30092020/7152

Copyright: (C) 2020 Mokhnar L. I., Fomych M. V., Diachkova O. M., Kryshtal M. A. This is an openaccess article distributed under the terms of the Creative Commons Attribution License (CC BY). The use, distribution or reproduction in other forums is permitted, provided the original author(s) or licensor are credited and that the original publication in this journal is cited, in accordance with accepted academic practice. No use, distribution or reproduction is permitted which does not comply with these terms.

Introduction. Today, the operational and rescue service of civil defence is going through a special stage of increasing requirements for the future specialists training. Among the tasks that society sets for the higher education system today, very important place belongs to instilling in future specialists a sense of personal and professional responsibility for their actions and decisions, actions and behavior, for their attitude towards the other people, towards society as a whole and towards themselves.

Because of the peculiarities of the professional activities, future specialists of the civil defence service should have the ability to take responsibility in difficult situations, be confident in the decisions and themselves, be able to make the right decision in the absence of the necessary information, in the absence of time to comprehend it, the ability to maintain high activity; the ability to distribute and switch attention performing several actions, functions, tasks. The absence or poor development of these qualities reduces the effectiveness of professional activity. 
The goal of training and educating the future specialists of civil defence service in establishments of higher education is not just their mastery of a certain amount of knowledge, but the formation of their readiness to take responsibility of their own decisions and actions, a sense of high responsibility for the assigned task.

Analysis of recent studies and publications, that started solving this problem. The analysis of recent studies in this area shows that the issues of the formation of responsible behavior have been studied by many scientists. For example, the problem of professional responsibility was studied by philosophers A. A. Dolskyi, I. V. Vladlenova, A. N. Gorodiskaya, V. I. Mishchenko, M. V. Smoliaga and others, who consider the essence of a person as the relationship between his/her freedom and responsibility; sociologists G. S. Afanasiev, T. N. Baidak, V. A. Bolotova, A. D. Goiko, B. D. Golovanov, O. Yu. Klimenko, L. N. Kogan, A. F. Plakhotnyi, I. P. Ruschenko and others who consider responsibility as an objective necessity of the relationship between the individual and society; psychologists J. B. Bogdan, L. S. Vygotskyi, A. V. Dolgarev, A. E. Knysh, G. V. Popova, M. V. Savchyn, B. I. Furmanets and others, who qualify responsibility as one of the main qualities of a person, as a result of the integration of all his/her mental functions and an objective perception of the surrounding reality, a strong-willed attitude to duty; teachers T. V. Gura, A. A. Ignatiuk, N. V. Podbutskaya, A. S. Ponomariov, S. M. Reznik, A. G. Romanovskyi, M. K. Chebotarev and others, who pointed out that the formation and development of a sense of responsibility is an important component of the pedagogical problem, to the solution of which all education should be directed from parental influence on children from an early age to higher education.

The study and analysis of the psychological and pedagogical literature allows us to assert that the great number of works is devoted to certain aspects of responsibility. The problem that would reveal the essence and content of the formation of responsible behavior of cadets in the educational process of higher educational establishments has been poorly studied for today. The contradictions between the insufficient development of this problem in scientific sources and the need to solve it in the pedagogical process of establishments of higher education actualize the aspect of the search that we have chosen.

Presentation of the main material. The analysis of psychological and pedagogical literature indicates that the problem of the formation of the responsibility of the individual was studied by many teachers of different times and formations, and it is relevant today.

The study of the scientific sources shows that the word "responsibility" was introduced by A. Bain in the book "Emotions and Will". Responsibility is associated with the issue of punishment, because any issue that arises when discussing this term is a matter of accusation, conviction and punishment. D. Mill, like A. Bane, associates responsibility with punishment [2].

The psychological literature examines a wide range of issues related to the definition of the parameters of responsible behavior, ways and means of education of the responsible attitude to socially useful activities, identifying the mechanisms for the responsibility formation. The researcher of the problem of the psychology of responsibility K. Muzdybaev notes that etymologically the word responsibility comes from the verb "to be in charge" and refers to the Old Slavonic concept - "veche", which meant advice, agreement, consent [4].

S. Rubinstein considers the responsibility to be the embodiment of a true, deep and principal attitude to life. This is not only an individual's awareness of all the consequences of what has already been done, but also "the ability of a person to determine events, actions at the time of their commission and in the process of implementation until a radical change in his/her whole life". At the same time, the researcher noted that responsibility is not the devotion to formal duty, dogma, adherence to the established rules, but "the ability to see, highlight, create problems during the life, recognize them in time and make responsible decisions".

So, it can be insisted that S. Rubinstein defines responsibility not only as a task, an act required by the circumstances or social norms, but that actions that it could carry out. In such way the potential aspect of responsibility is developed [5].

M. Savchin studied the psychological foundations of responsible behavior in details. In his opinion, the essential sign of an individual's inner urge to such behavior is the meaning of the subject of responsibility, in which the necessary and the desired, the possible and the actual, the conscious and the unconscious, the rational and the emotional are integrated. The process of motivation of responsible behavior starts at successive stages of initiation, choice, intention formation, its 
implementation and rethinking, each of which is determined by a system of conditions and factors, and mediated by the functioning of specific socio-psychological mechanisms.

The mechanism of subsequent comprehension is the cognitive-emotional assessment of an act or an intention that has been accepted, although not realized, as a result of which new impulses arise and are recorded for the implementation of responsible behavior in the future. Among the general mechanisms that ensure the acceptance of duty, M. Savchin singles out infection, imitation of important adults, identification with them, empathy, awareness, meaning formation and self-regulation [6].

From the point of view of philosophical understanding of the category of "responsibility", it can be noted that there are significant differences between "responsibility" and "responsible attitude". As the analysis of scientific sources (N. Kuznetsova, V. Morozova, V. Safin, G. Tulchinskyi, etc.) shows, the responsible attitude is a situational characteristic, and responsibility is an essential one, which reflects a stable personality quality. The same categorical differences exist between the concepts of "responsibility" and "social responsibility", since responsibility reflects the moral and ethical aspects of the individual, and social responsibility - socio-professional and socio-behavioral.

According to A. Spirkin, "the objective basis of the person's responsibility to society and himself/herself is the real connection between society and the individual, which always has a contradictory character. There are social norms, but there is also freedom of choice, including the ability to violate them. If there is no choice, there is no responsibility either". [7].

Foreign authors study the problem of the formation of responsibility as the moral development of the individual, and identify certain interrelated stages in the formation of moral consciousness, and, consequently, responsibility (J. Piaget, L. Kolberg).

The number of authors studies the responsibility in the structure of the personality as: this concept is considered both as a personality trait, and as an individual typological feature, and as a professionally important quality, and as a category of relations. Common to all the qualities that characterize responsibility is the normative nature of the individual, its loyalty to group standards and diligence in the performance of the duties. Responsibility is the result of the integration of all mental functions of an individual: subjective perception of the surrounding world, assessment of the life resources, emotional attitude to duty, will [1].

In the context of the problems we are studying, especially important is the concept of "professional responsibility". Professional responsibility does not appear by itself, it starts to form with the beginning of work activity, for future specialists of civil defence service - with the beginning of educational activities. The peculiarities of the educational activity of cadets in the establishments of higher education are the following:

- strict regulation of the daily routine;

- combination of educational activities with the duty performance;

- submission and subordination;

- the advantage of group activities.

However, it is especially important to note that arrival at the place of study also leads to significant changes in the interpersonal contacts, social status, life stereotypes, the system of relationships that has developed with others and requires a revision of attitudes, relationships, ideas about social roles, so that they were adequate in the new conditions. That is why the educational process in establishments of higher education should be organized in such way as to enable cadets to form a sufficient and high level of professional responsibility during their study [3].

The responsible behavior of an individual does not form by itself, by the development of general educational, cultural level and even by social activity of the individual. A person cannot be forced to act responsibly - strict regulations, punitive sanctions do not always help; numerous appeals did not give an effective effect; educational work, aimed at developing a sense of responsibility for the assigned task, did not always show an influence. To effectively and purposefully solve this problem, it is necessary systematically study the degree of formation of professional responsibility.

The main mechanism of the formation of a responsible attitude towards the performing the functional duties by the future rescuers is not just the declaration of certain norms of behavior, as the compliance with these norms of behavior of commanders and chiefs, that is, strengthening of the norm through a social model. In addition, responsibility should be seen as a firm personality measure. Responsible specialists are characterized by the presence of positive qualities, beginning from the punctuality, accuracy and ending with moral, civic features, such as honesty, justice, adherence to 
principles, etc. These qualities are at the root of political, legal, moral, professional, social and other types of responsibility. Educational work should be directed at their formation even during the study of cadets in the establishments of higher education [3].

The phenomenon of professional responsibility of representatives of risky professions has its own characteristics. It is present in various degrees among all specialists, and it also exerts special psychological pressure on chiefs. So, for example, the realization during a critical situation of the fact that people's lives depend on the decision, can become a strong stressful factor for a person. High responsibility, high requirements for self-organization are an integral part of the work; that's why responsibility must be a stable personality feature of the firefighter-rescuer.

The consciousness of firefighters-rescuers goes through many negative sociogenic factors that significantly reduce the responsibility and effectiveness of professional activities.

The main ways and means that ensure the success of the process of formation of responsibility include: the formation of the motivation of responsibility among cadets; active involvement of cadets in activities to master the skills of responsible behavior in the roles of: performer, organizer and leader; individual approach, taking into account the level of responsibility formation; the spread of independence among cadets in various activities; self-education of responsibility among cadets.

In our opinion, the effectiveness of the process of the responsibility formation will greatly increase if the cadets, realizing the importance of such a property, are interested in the formation, and also the pedagogical conditions adequate to the target goal are created. The main pedagogical conditions for improving educational activity in the formation of responsibility among cadets include: organization of combined educational activity, which provides the responsible dependence; expanding the independence of cadets in educational activities; the personal example of teachers of higher education establishments and training officers in the responsible performance of duties; exact organization of the educational process.

Conclusions. Thus, the conducted theoretical analysis of psychological, pedagogical and philosophical literature allows us to conclude that the professional responsibility of a rescuer is an integrative quality of civil defence service specialists, that appeared in their ability to make right decisions in the field of their professional activities, to be persistent and conscientious in their implementation and willingness to be responsible for their results and consequences. The high level of responsibility of specialists of civil defence service contributes to the performance of their main responsibilities at the high professional level.

Directions for future research. The article does not describe all aspects of the researched problem. A separate area of further research in this context, requiring scientific and methodological justification, may be the development of guidelines for the formation of responsibility among future specialists of civil defence service and analysis of the main areas of work to form this professionally important quality of future rescuers during their studies in establishments of higher education.

\section{REFERENCES}

1. Manuilov Ye. M. Moral and ethical responsibility of the agent activity / Ye. M. Manuilov // Bulletin Nat. Jurid. Acad. of Ukraine named after Yaroslav the Wise. Series: Philosophy, Philosophy of Law, Politics, Sociology / editorial board: A.P. Getman and others - Kh.: Pravo, 2011. - Edition 9. - 24-31 p.

2. Mill John Stewart / Encyclopedical Dictionary of Brockhaus and Efron: In 86 volumes (83 vol. I 4 additional) St. Petersburg, 1890. - $34 \mathrm{p}$.

3. Mokhnar L. I. The problem of the responsibility formation as the professionally important quality of the future specialists of civil defence service / L. I. Mokhnar // New Technologies of Science: Sciences. method. collection / Institute of Innovation Technologies and Education of the Ministry of Education and Science of Ukraine. - 2015. - Edition 84. P. - 126 - 130.

4. Muzdybaev K. Psychology of responsibility / K. Muzdybaev. - L.: Nauka, 1983. - 240 p.

5. Rubinstein S. L. Fundamentals of General Psychology: in 2 volumes. Vol. II / S. L. Rubinstein. - M., 1989. - 328 p.

6. Savchyn M. V. Responsibility: the principle of motivational regulation of behavior of personality / M. V. Savchyn // Pedagogy and psychology. - 1996. - № 1. - P. 10-18.

7. Spirkin A. G. Consciousness and self-awareness / A. G. Spirkin. - M.: Education, 1972. - 344 p. 